\title{
Development and Characterization of Novel Composite Films Based on Soy Protein Isolate and Oilseed Flours
}

\author{
Magdalena Mikus, Sabina Galus *(D), Agnieszka Ciurzyńska $\mathbb{D}^{D}$ and Monika Janowicz \\ Department of Food Engineering and Process Management, Institute of Food Sciences, Warsaw University of Life \\ Sciences-SGGW, 159c Nowoursynowska St., 02-776 Warsaw, Poland; magdalenamikus1996@gmail.com (M.M.); \\ agnieszka_ciurzynska@sggw.edu.pl (A.C.); monika_janowicz@sggw.edu.pl (M.J.) \\ * Correspondence: sabina_galus@sggw.edu.pl; Tel.: +48-22-593-75-79
}

check for

updates

Citation: Mikus, M.; Galus, S.; Ciurzyńska, A.; Janowicz, M. Development and Characterization of Novel Composite Films Based on Soy Protein Isolate and Oilseed Flours. Molecules 2021, 26, 3738. https:// doi.org/10.3390/molecules26123738

\section{Academic Editors:}

Assunta Marrocchi, Roland Franz and Frank Welle

Received: 26 April 2021

Accepted: 16 June 2021

Published: 19 June 2021

Publisher's Note: MDPI stays neutral with regard to jurisdictional claims in published maps and institutional affiliations.

Copyright: (c) 2021 by the authors. Licensee MDPI, Basel, Switzerland. This article is an open access article distributed under the terms and conditions of the Creative Commons Attribution (CC BY) license (https:/ / creativecommons.org/licenses/by/ $4.0 /)$.
Abstract: The possibility of using oilseed flours as a waste source for film-forming materials with a combination of soy protein isolate in preparation of edible films was evaluated. Physical, mechanical and barrier properties were determined as a function of the oilseed type: hemp, evening primrose, flax, pumpkin, sesame and sunflower. It was observed that the addition of oilseed flours increased the refraction and thus the opacity of the obtained films from 1.27 to $9.57 \mathrm{~A} \mathrm{~mm}^{-1}$. Depending on the type of flours used, the edible films took on various colors. Lightness $\left(\mathrm{L}^{*}\right)$ was lowest for the evening primrose film $\left(\mathrm{L}^{*}=34.91\right)$ and highest for the soy protein film $\left(\mathrm{L}^{*}=91.84\right)$. Parameter $\mathrm{a}^{*}$ was lowest for the sunflower film $\left(a^{*}=-5.13\right)$ and highest for the flax film $\left(a^{*}=13.62\right)$. Edible films made of pumpkin seed flour had the highest value of the $b^{*}$ color parameter $\left(b^{*}=34.40\right)$, while films made of evening primrose flour had the lowest value $\left(b^{*}=1.35\right)$. All analyzed films had relatively low mechanical resistance, with tensile strength from 0.60 to 3.09 MPa. Films made of flour containing the highest amount of protein, pumpkin and sesame, had the highest water vapor permeability, 2.41 and $2.70 \times 10^{-9} \mathrm{~g} \cdot \mathrm{m}^{-1} \mathrm{~s}^{-1} \mathrm{~Pa}^{-1}$, respectively. All the edible films obtained had high water swelling values from 131.10 to $362.16 \%$, and the microstructure of the films changed after adding the flour, from homogeneous and smooth to rough. All blended soy protein isolate-oilseed flour films showed lower thermal stability which was better observed at the first and second stages of thermogravimetric analysis when degradation occurred at lower temperatures. The oilseed flours blended with soy protein isolate show the possibility of using them in the development of biodegradable films which can find practical application in the food industry.

Keywords: edible films; soy protein; oilseed flour; mechanical and barrier properties

\section{Introduction}

Edible films and coatings obtained on the basis of biopolymers are bio-based packaging which can find applications as protective coatings or be consider as bioplastics used for food packaging. They are made of renewable and biodegradable materials that are suitable regarding environmental issues. Carbohydrates and proteins are commonly used in the production of films, but in order to improve their properties, additives of other ingredients, e.g., lipids, are used [1]. Today, edible films find many applications in the food industry because the application of a thin-film layer on or between food components enables an improvement in the quality of the product, as well as the extension of its shelf life when applied as a protective edible coating for fruits or vegetables. In addition, edible films protect food products against mechanical damage and protect the product against the adverse effects of physical, chemical and microbiological factors [2]. The most commonly used biopolymers for their synthesis are proteins, polysaccharides and lipids, and it is also possible to obtain composite films. The ingredients used in the film are mostly of plant origin, e.g., waxes, oils, zein or cellulose [3]. A frequently investigated ingredient for creating biodegradable films is soy protein isolate because it is an inexpensive, readily 
available and nutritious protein. Previous studies show that soy protein isolate has good film-forming properties, creating films with adequate mechanical and barrier properties. Edible films based on soy protein isolate are characterized by a significant smoothness and flexibility [4].

The hypothesis of this research was to use oilseed flours as film-forming materials in order to recycle these waste materials after the production of oils. Preliminary research showed that films obtained only from oilseed flours were brittle and did not form a continuous structure. Therefore, soy protein isolate, a similar plant-source polymer, was used as a film-forming material. Oilseeds are grains that contain a high fat content, which may exceed $40 \%$. The growing interest in oilseeds in recent times results from a better understanding of their chemical composition, and the factors that influence it include environmental conditions, genetic conditions and conditions during the processing of raw materials [5]. The seeds obtained from oilseeds are also a valuable source of vitamins and essential fatty acids (EFA) [6]. In recent years, the use of processing residues from the fruit and vegetable industry has aroused great interest in the production of edible materials. They are increasingly used for the production of flours, which have a promising potential for the production of film-forming materials [7]. Flours are materials that have a lower shelf life than grains. This is due to damage to the seed coat during the production process [8]. Flours made from legumes can also be used as a film-forming material. In addition to being a good film-forming material, they are a good source of nutritional protein and also contain numerous vitamins and minerals [2]. To date, there has been little research conducted using oilseed flours to form edible films. On the other hand, research was carried out to obtain edible films from other types of flours, including eggplant flour and corn starch [9], quinoa [10] and chia seeds [11]. According to the obtained results, it was found that most of the obtained edible films were characterized by a heterogeneous structure and poor mechanical properties. Ochoa-Yepes, Medina-Jaramillo, Guz and Famá [12] investigated cassava starch films prepared with the addition of lentil flour, made from residues from the production of lentil protein. The addition of flour made the edible films characterized by a higher breaking strength and greater elasticity and flexibility. Another alternative source for the production of biodegradable films is achira flour. Films obtained from this flour were characterized by low solubility in water and relatively good barrier resistance against water vapor [13].

The aim of this study was to develop and characterize functional properties of edible films based on different types of oilseed flours and soy protein isolate. According to the authors' knowledge, the types of flours used in this work were used for the first time as edible films, which would be an innovative "novelty" and an interesting means for commercial use as well as an alternative to the use of chemical treatments. The influence of adding flour on the thickness, water solubility, swelling index, optical properties (opacity and color), water vapor permeability, sorption kinetics, microstructure and mechanical and thermal properties of the films was analyzed. The size of the oilseed flour particles was also determined.

\section{Results}

\subsection{Oilseed Flour Particle Size Measurement}

Flour is a heterogeneous mixture of particles of various sizes, densities and shapes. Figure 1 shows a diagram of the dependence of the size of the flour fraction on the share of individual fractions in a given type of oilseed flour (evening primrose, flax, hemp, pumpkin, sesame and sunflower). Detailed granulometric analysis showed that in all types of commercial flours used, the 355 and $500 \mu \mathrm{m}$ fractions constituted the highest percentage. The highest value describing the content of the fraction of $710 \mu \mathrm{m}$ was observed for sunflower flour, which was characterized by high cohesiveness. Pumpkin seed flour is characterized by a high content of iron and copper, while sesame flour is a rich source of calcium and has emulsifying properties [14]. Sesame protein isolate, which is used in food coatings, is obtained from sesame flour obtained after an extraction process to 
obtain oil [15]. According to Patwa, Malcolm, Wilson and Ambrose [16], the flour particle size is an important quality parameter because the size of the particles affects the type of processing technique used and generates the final product quality. Due to the simplicity and ease of analysis in laboratory conditions, sieve analysis is a method often used in the industry. Those authors observed the geometric mean particle diameter for hard red and soft white wheat flours at 142.30 and $693.10 \mu \mathrm{m}$, respectively. This range, observed for $10 \mathrm{~min}$ of sieving time, is similar to the values obtained for the analyzed oilseed flours. Seeds characterized by greater hardness have a stronger bond between the starch and protein, which also results in larger flour particles. The observed differences in the content of individual fractions may depend on the heterogeneity of the chemical composition of the raw material and the type of flour production process. In order to improve fluidity and enable easier screening of the cohesiveness of flour, an appropriate flow-improving agent should be used, e.g., calcium phosphate. Additionally, according to Adjei-Fremah et al. [17], the particle size distribution is a very important factor determining the functional properties, particularly the hydration properties and the quality of developed product. The hydration properties are greatly influenced by porosity, as well as by chemical features, which include the number and distribution of polar functional groups that have the ability to bind water. Those authors obtained the mean diameter of the volume distribution for whole cowpea flours between 33.3 and $432.3 \mu \mathrm{m}$, which is lower than that for the oilseed flours presented in this paper. Preliminary studies were performed for various oilseed flours, but crushing of the edible films occurred due to the large particles. To reduce the brittleness of the edible films, flours with fractions below $250 \mu \mathrm{m}$ were used for the preparation of films.

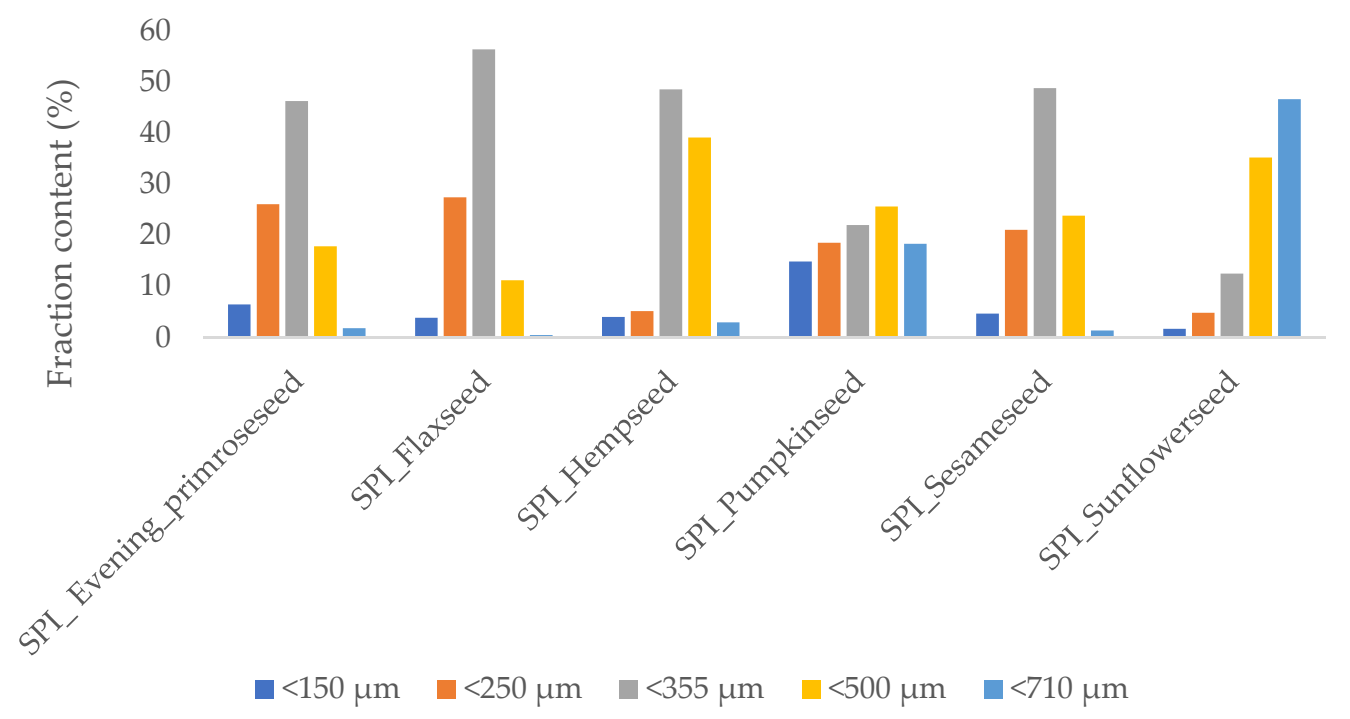

Figure 1. Fraction content in oilseed flours.

\subsection{Physical Properties}

\subsubsection{Water Content}

The tested edible films had a water content of $6.20-8.50 \%$ (Table 1), which had a significant impact on the physical and barrier properties of the films obtained. The films with the highest sugar content, i.e., those obtained on the basis of sunflower or linseed flour, achieved the highest percentage of water content and the greatest tendency to swell in water (Table 1). Higher values of water content (15.08-17.73\%) were obtained by Pajak, PrzetaczekRożnowska and Juszczak [18], who tested edible films based on starch from pumpkin, lentils and quinoa. Those authors observed that for films made of corn starch, ahipa and cassava, and with the addition of $30 \%$ glycerol, the moisture content is much higher at $15.3,19.8$ and $26.3 \%$ than in the case of films with a lower glycerol content. Glycerol is a hydrophilic plasticizer that has water-holding properties. Moreover, the addition of 
a plasticizer reduces the interactions between starch macromolecules [19]. Additionally, Andrade-Mahecha, Tapia-Blácido and Menegalli [20] obtained a higher water content in edible films made of achira flour $(18.2 \pm 0.7 \%)$. The high water content of edible films may be due to the high amount of hydrophilic components, such as protein, carbohydrates and fiber, in the flour. The high content of these ingredients can cause interactions with water molecules, which means that more water is retained in the edible film [9].

Table 1. Water content, thickness and water solubility of soy protein isolate-oilseed flour films.

\begin{tabular}{ccccc}
\hline Film & Water Content (\%) & Thickness $(\mu \mathrm{m})$ & Water Solubility (\%) & Swelling in Water (\%) \\
\hline SPI & $6.72 \pm 0.07^{\mathrm{ab}}$ & $120.50 \pm 12.50^{\mathrm{b}}$ & $100 \%$ & n.d. \\
SPI_ & $6.00 \pm 0.55^{\mathrm{a}}$ & $173.50 \pm 15.21^{\mathrm{a}}$ & $14.39 \pm 0.63^{\mathrm{abc}}$ & $191.78 \pm 4.93^{\mathrm{bc}}$ \\
Evening_primroseseed & $8.50 \pm 0.78^{\mathrm{c}}$ & $164.89 \pm 12.97^{\mathrm{a}}$ & $12.18 \pm 2.04^{\mathrm{ab}}$ & $362.16 \pm 4.01^{\mathrm{d}}$ \\
SPI_Flaxseed & $6.88 \pm 0.31^{\mathrm{ab}}$ & $164.78 \pm 16.69^{\mathrm{a}}$ & $15.76 \pm 1.41^{\mathrm{bc}}$ & $170.43 \pm 16.23^{\mathrm{b}}$ \\
SPI_Hempseed & $6.50 \pm 0.53^{\mathrm{ab}}$ & $155.88 \pm 18.04^{\mathrm{a}}$ & $11.38 \pm 2.33^{\mathrm{a}}$ & $131.10 \pm 1.86^{\mathrm{a}}$ \\
SPI_Pumpkinseed & $7.92 \pm 0.48^{\mathrm{bc}}$ & $167.57 \pm 16.20^{\mathrm{a}}$ & $17.25 \pm 1.41^{\mathrm{c}}$ & $139.78 \pm 5.52^{\mathrm{a}}$ \\
SPI_Sesameseed & $8.45 \pm 0.56^{\mathrm{c}}$ & $137.60 \pm 14.25^{\mathrm{b}}$ & $13.80 \pm 1.65^{\mathrm{abc}}$ & $206.58 \pm 8.68^{\mathrm{c}}$ \\
SPI_Sunflowerseed & &
\end{tabular}

Mean values with standard deviations in brackets. Different superscript letters ${ }^{\left({ }^{a}-d\right.}$ ) within the same column indicate significant differences between the films $(p<0.05)$ (n.d.-not determined).

\subsubsection{Thickness}

Differences were observed in the edible films obtained, despite the use of the same amount of ingredients for the preparation of film-forming solutions (Table 1). The control film of soy protein isolate $(120.5 \pm 12.50 \mu \mathrm{m})$ and the film of sunflower flour $(137.6 \pm 14.25 \mu \mathrm{m})$ were characterized by the lowest thickness. The film made of evening primrose flour was characterized by the highest thickness value $(173.5 \pm 15.21 \mu \mathrm{m})$. The differences in thickness may have been due to the different densities of the prepared film-forming solutions, since viscous solutions tend to form thicker layers. In films obtained from pinhão flour by Daudt et al. [21], the thickness varied with total solids, from $0.039 \mathrm{~mm}$ for films without glycerol to $0.057 \mathrm{~mm}$ for films with $1.5 \%$ glycerol. The differences in the thickness of the homogeneous films did not significantly affect the water vapor permeability or the mechanical properties of the films. Chandla et al. [22] obtained amaranth, buckwheat and corn starch films with an average thickness of $0.24,0.28$ and $0.29 \mathrm{~mm}$, characterized by a uniform and smooth surface.

\subsubsection{Water Solubility}

The potential application of edible films may require a high water resistance to increase the product integrity and obtain a moisture-resistant package. In other instances, however, good solubility of the films prior to use may be desired, such as when encapsulating food additives [23]. Control films made of soy protein isolate were characterized by significant water solubility, similar to the study by Galus [4], while films with the addition of oilseed flour did not dissolve when placed in water (Table 1).

Aydogdu et al. [24], when analyzing the obtained lentil flour edible films, observed that the films retained their physical integrity. The solubility of the tested films with the addition of oilseed flour was quite low, and the lowest solubility value was found for the pumpkin seed flour film, which, compared to the composition of other flours used, contained the largest amount of fat. According to Basiak, Lenart and Debeaufort [25], the water solubility of starchy materials is related to the amylose content. Those authors obtained water solubility in the range $30.16-34.76 \%$, which is much higher than that for the analyzed films here. The higher the amylose content of the flours used, the lower the water solubility index of the films. The differences in the obtained values may also result from the different thicknesses of the films and the inhomogeneous and porous structure. According to Gutiérrez [26], the presence of methyl groups derived from pumpkin flour in edible films reduces the number of hydroxyl groups that have the ability to remove moisture. In addition, nanocomposites incorporated into edible films may reduce their hydrophilicity. 


\subsubsection{Swelling Index}

The ability of the edible films to swell in water is an important parameter as it provides information about the water resistance of the tested packaging materials. It also helps maintain the quality of food products during storage. The prepared edible films showed a swelling parameter in the range of $131.10-362.16 \%$ (Table 1), while the film made of soy protein isolate lost its integrity and dissolved when placed in water. The highest value of swelling in water was obtained for the flaxseed flour edible film $(362.16 \%)$, and the lowest was obtained for the pumpkin seed flour film (131.10\%). The films of sesame flour and pumpkin seeds, which had the highest content of fat in their composition, showed a similar dependence of swelling after being placed in water. Edible films that tend to absorb a large amount of water can alter the appearance, texture, durability and taste of the coated food product [27]. Starch-based films developed by Basiak, Debeaufort and Lenart [28] had a water swelling value of $40 \%$ when placed in distilled water for $2 \mathrm{~min}$. High swelling values in water at the level of $126 \pm 1-500 \pm 13 \%$ were also obtained by Pajak, Przetaczek-Rożnowska and Juszczak [18]. Those authors tested starch-based films but placed the films in distilled water for $24 \mathrm{~h}$. Moreover, those authors observed a similar relationship because the films after this treatment were not damaged, unlike the films made on the basis of oilseed flours. The high water resistance of edible films depends on the ratio of amylose to amylopectin present in the polymers. Further studies are recommended to better define the interactions between amylose, amylopectin, glycerol and water and biopolymers. As a result, it will be possible to better determine their influence on the properties of edible films.

\subsubsection{Film Opacity}

The opacity of the edible films is a very important parameter as it determines the visibility of the packaged food products to consumers. Opacity also determines the ability of materials to refract light, and the obtained results indicate greater refraction of light, resulting from the presence of flours in the film-making material (Table 2).

Table 2. Color attributes $\left(\mathrm{L}^{*}, \mathrm{a}^{*}, \mathrm{~b}^{*}\right)$ and total color difference $(\Delta \mathrm{E})$ of soy protein isolate-oilseed flour films.

\begin{tabular}{|c|c|c|c|c|c|}
\hline Film & $\mathbf{L}^{*}$ & $a^{*}$ & $\mathbf{b}^{*}$ & $\Delta \mathrm{E}$ & Film Opacity $\left(\mathrm{A} \mathrm{mm}^{-1}\right)$ \\
\hline SPI & $91.84 \pm 1.05^{f}$ & $-3.18 \pm 0.21^{b}$ & $25.72 \pm 2.39^{b}$ & $92.04 \pm 1.51^{\mathrm{f}}$ & $1.27 \pm 0.28^{c}$ \\
\hline $\begin{array}{l}\text { SPI_ } \\
\text { Evening primroseseed }\end{array}$ & $34.91 \pm 1.13^{b}$ & $6.99 \pm 0.71^{\mathrm{d}}$ & $1.35 \pm 0.66^{\mathrm{c}}$ & $64.82 \pm 0.99^{a}$ & $9.57 \pm 0.74^{\mathrm{e}}$ \\
\hline SPI_Flaxseed & $54.28 \pm 3.03^{a}$ & $13.62 \pm 0.96^{\mathrm{e}}$ & $21.06 \pm 2.11^{\mathrm{a}}$ & $65.42 \pm 2.47^{\mathrm{a}}$ & $7.15 \pm 0.96^{b}$ \\
\hline SPI_Hempseed & $63.16 \pm 3.18^{c}$ & $8.66 \pm 0.90^{\mathrm{d}}$ & $30.24 \pm 1.33^{\mathrm{d}}$ & $47.17 \pm 2.04^{c}$ & $3.85 \pm 0.64^{d}$ \\
\hline SPI_Pumpkinseed & $71.46 \pm 1.56^{\mathrm{d}}$ & $-1.80 \pm 0.73^{b}$ & $34.40 \pm 0.39 \mathrm{e}$ & $71.69 \pm 1.36^{\mathrm{e}}$ & $5.59 \pm 1.22^{\mathrm{a}}$ \\
\hline SPI_Sesameseed & $83.40 \pm 1.08^{\mathrm{e}}$ & $1.15 \pm 0.37^{c}$ & $25.21 \pm 1.05^{b}$ & $28.74 \pm 1.34^{b}$ & $6.12 \pm 0.56^{\mathrm{a}}$ \\
\hline SPI_Sunflowerseed & $51.97 \pm 2.85^{\mathrm{a}}$ & $-5.13 \pm 0.99^{\mathrm{a}}$ & $19.88 \pm 2.23^{a}$ & $51.18 \pm 1.83^{\mathrm{d}}$ & $7.57 \pm 0.67^{b}$ \\
\hline
\end{tabular}

Mean values with standard deviations in brackets. Different superscript letters ${ }^{\mathrm{a}-\mathrm{f}}$ ) within the same column indicate significant differences between the films $(p<0.05)$.

According to Acquah, Zhang, Dube and Udenigwe [29], high film opacity values are associated with the presence of phenolic compounds in the samples tested. However, according to Zheng, Yu and Pilla [30], good barrier properties against UV radiation are due to the presence of amino acid residues in proteins that have the ability to absorb UV radiation. The opacity value of the edible films obtained from bocaiuva flour ranged from 3.8 to $9.3 \mathrm{~A} / \mathrm{mm}$ [31]. Films obtained on the basis of peas by Giosafatto et al. [2] had an opacity value of $7.74 \pm 0.26$ at a wavelength of $600 \mathrm{~nm}$. The result obtained was also similar to the bean (Phaseolus vulgaris) and pea (Pisum sativum) protein hydrocolloid films obtained by Shevkani and Singh [32]. The film opacity for the soy films obtained by Ortiz et al. [33] was $1.00 \pm 0.05$ for films dried at $50{ }^{\circ} \mathrm{C}$ and $1.50 \pm 0.05$ for films dried at $40{ }^{\circ} \mathrm{C}$. 


\subsubsection{Color}

The color of edible films is a very important parameter influencing the acceptance of products by consumers; therefore, transparent, bright and almost invisible films are mostly expected. The color of the films obtained varied depending on the type of flour used. The control films were characterized by high brightness and transparency, while the films containing added flour were opaque. The color values of the obtained edible films are presented in Table 2. The results show that the lowest brightness, 34.91 (parameter $\mathrm{L}^{*}$ ), and the darkest color were found for the evening primrose flour film. The highest value of the $L^{*}$ brightness parameter was obtained for the edible film from the SPI soy protein isolate (91.84). Films made from banana peel flour by de Faria Arquelau et al. [34] had a yellow color, and the obtained $L^{*}$ value was 82.47 . It was also found that the value of the brightness parameter was influenced by the heating time. The shorter the heating time, the greater the brightness of the edible film. The $\mathrm{a}^{*}$ color parameter of the obtained edible films ranged from -5.13 for the sunflower flour film to 13.62 for the linseed flour film. Positive values of the $\mathrm{a}^{*}$ parameter indicate a greater proportion of red, while negative values indicate the presence of a greater proportion of green. The highest proportion of green color was observed for the film made of sunflower flour, the film-forming solution of which, after adding $\mathrm{NaOH}$ solution, changed the color from light brown to green. The differences in the colors of the edible films depended on the type of flour additive used and were characterized by significant differences $(p<0.05)$. Additionally, the addition of flour resulted in a significant deviation from the pattern of the soy protein isolate film and an increase in the amount of dyes present $(\Delta \mathrm{E})$. The obtained values of the absolute color difference $(\Delta \mathrm{E})$ in the range $27.47-64.82$ showed a significant deviation from the standard. According to the criterion adopted by the International Commission on Lighting, the values in the range 0-2 are unrecognizable for humans. An inexperienced observer will recognize color deviation differences in the range of 2-3.5, while clear differences are visible at values higher than 3.5 [35]. Maniglia, Tessaro, Lucas and Tapia-Blácido [36] also obtained high values of the absolute color difference for babassu mesocarp flour films in the range $22.46 \pm 0.89-41.77 \pm 0.48$.

\subsection{Water Vapor Permeability, Sorption and Diffusion}

One of the main purposes of using edible films is to control the possibility of water vapor migration between the coated food product and the surrounding atmosphere. Therefore, the aim is to achieve a relatively low water vapor permeability. The control film from soy protein isolate had the most compact structure and the lowest water vapor permeability parameters, while the films containing added flour had higher values (Table 3). It was observed that films of pumpkin seed flour and sesame flour, which contained the highest amount of protein in their composition, were characterized by the highest water vapor permeability value. According to [10], the presence of proteins and soluble fibers in flour increases the number of interactions between flour components and water molecules, which increases the water vapor permeability of the film. Wu et al. [37] obtained water vapor permeability values for pomelo flour films in the range $2.02 \pm 0.02-2.95 \pm 0.07 \times 10^{-12} \mathrm{~g} \mathrm{~cm} \mathrm{~cm}^{-2} \mathrm{~s}^{-1} \mathrm{~Pa}^{-1}$. According to those authors, a greater water vapor barrier results from the formation of denser composite film systems. On the other hand, the permeability for the films of achira flour was $5.3 \pm 0.2 \times 10^{-10} \mathrm{~g} \mathrm{~m}^{-1} \mathrm{~s}^{-1} \mathrm{~Pa}^{-1}$ [20], for films based on quinoa, it was $0.6 \pm 0.1 \times 10^{-10} \mathrm{~g} \mathrm{~m}^{-1} \mathrm{~s}^{-1} \mathrm{~Pa}^{-1}[22]$ and for banana flour films, it was $2.1 \pm 0.2 \times 10^{-10} \mathrm{~g} \mathrm{~m}^{-1} \mathrm{~s}^{-1} \mathrm{~Pa}^{-1}$ [38]. 
Table 3. Water vapor permeability (WVP) at relative humidity difference of $50-100 \%$ and water diffusion of soy protein isolate-oilseed flour films.

\begin{tabular}{|c|c|c|}
\hline Film & $\begin{array}{c}\text { WVP } \\
\left(10^{-9} \mathrm{~g} \mathrm{~m}^{-1} \mathrm{~s}^{-1} \mathrm{~Pa}^{-1}\right)\end{array}$ & $\begin{array}{l}\text { Water Diffusion } \\
\left(10^{-14} \mathrm{~m}^{2} \mathrm{~s}^{-1}\right)\end{array}$ \\
\hline SPI & $1.49 \pm 0.13^{\mathrm{a}}$ & $0.80 \pm 0.00^{\mathrm{e}}$ \\
\hline SPI_Evening_primroseseed & $2.28 \pm 0.33^{\mathrm{e}}$ & $1.65 \pm 0.07^{\mathrm{c}}$ \\
\hline SPI_Flaxseed & $1.82 \pm 0.28^{\mathrm{c}}$ & $1.40 \pm 0.06^{\mathrm{ab}}$ \\
\hline SPI_Hempseed & $1.94 \pm 0.17^{\mathrm{d}}$ & $1.55 \pm 0.07^{b c}$ \\
\hline SPI_Pumpkinseed & $2.41 \pm 0.27^{\mathrm{f}}$ & $1.35 \pm 0.07^{\mathrm{a}}$ \\
\hline SPI_Sesameseed & $2.70 \pm 0.38^{g}$ & $1.50 \pm 0.06^{\mathrm{ab}}$ \\
\hline SPI_Sunflowerseed & $1.64 \pm 0.21^{b}$ & $1.15 \pm 0.07^{\mathrm{d}}$ \\
\hline
\end{tabular}

Mean values with standard deviations in brackets. Different superscript letters ${ }^{\left({ }^{-}-\mathrm{g}\right.}$ ) within the same column indicate significant differences between the films $(p<0.05)$.

The shape of the curves of the dependence of the amount of adsorbed water on time is, in all cases, characterized by a similar shape (Figure 2). The highest increase in water content was recorded for the film made of pumpkin seed flour, while the lowest value and thus the highest surface hydrophobicity were found for the film made of evening primrose flour. It was observed that in the first hours of the process, there was the fastest increase, while in the following hours, it stabilized, but without reaching equilibrium due to hygroscopicity. According to Tapia-Blácido, do Amaral Sobral and Menegalli [38], edible films of amaranth flour that are plasticized with glycerol rather than sorbitol have an improved equilibrium water-holding capacity. Films with glycerol, even at high temperatures, have been found to be more hygroscopic than those plasticized with sorbitol. Due to the greater affinity of glycerol to water, it is possible to obtain a better plasticizing effect.

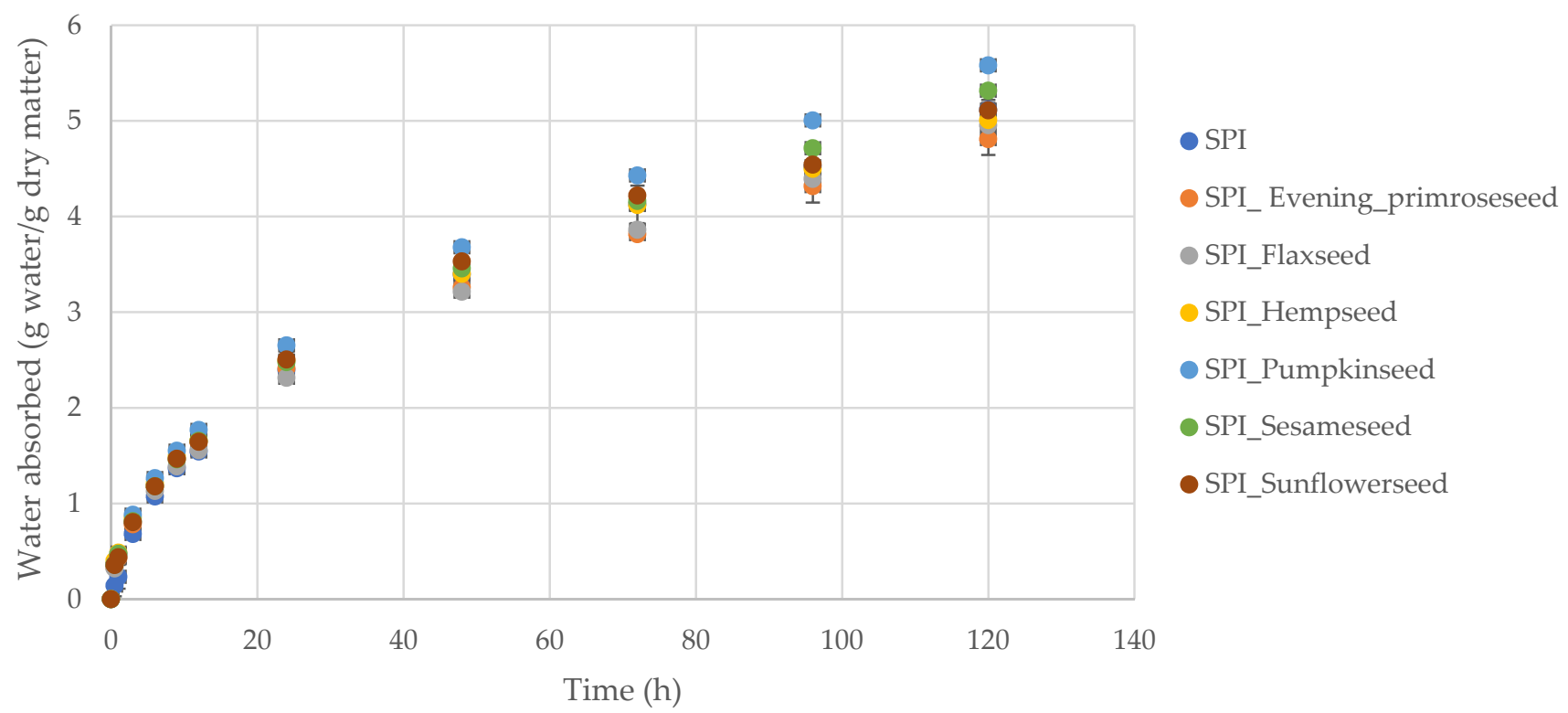

Figure 2. Kinetics of water vapor adsorption by soy protein isolate-oilseed flour films.

Table 3 shows the water vapor diffusion coefficient values for soybean films with oilseed flour added. It was observed that the addition of flours caused an increase in the value of the water vapor diffusion coefficient, which could have been caused by an increase in the porosity of the films resulting from the addition of flours, as well as different chemical compositions. Dias, Müller, Larotonda and Laurindo [11], for films based on rice flour, obtained values of the water vapor diffusion coefficient in the range $1.2-6.6 \times 10^{-13} \mathrm{~m}^{2} \mathrm{~s}^{-1}$. On the other hand, Zhao et al. [39], for films with the addition 
of rice flour, obtained values of the water vapor diffusion coefficient in the range from $3.06 \times 10^{-14}$ to $2.48 \times 10^{-15} \mathrm{~m}^{2} \mathrm{~s}^{-1}$.

\subsection{Microstructure}

Figure 3 shows the scanning microscope photographs of the surfaces and sections of the analyzed films. The control films from the soy protein isolate had a homogeneous and smooth surface, while the films made with oilseed flours were heterogeneous and rough. On the surface of the tested films, there were irregularly arranged fat drops, which differed in size and shape. Irregular cracks are visible in the micrograph of the surface of films made of pumpkin seed flour. The highest surface roughness was observed in the case of films made of evening primrose flour. According to Gutiérrez and González [40], the rougher the coating, the more opaque the film. The consistent morphology of the edible films makes it possible to reduce water adsorption and film polarity. However, according to Drakos et al. [41], the differences resulting from the consistency of the films could be due to the different contents of protein and carbohydrates in the flours used. Additionally, Silva, Cortez-Vega, Prentice and Fonseca [31], analyzing the obtained edible films from bocaiuva flour, observed a porous structure and unevenness of the film surface, which could interfere with water vapor diffusion. Those researchers also observed the presence of lipid globules separated from the starch matrix found in the darker regions of the films.

A
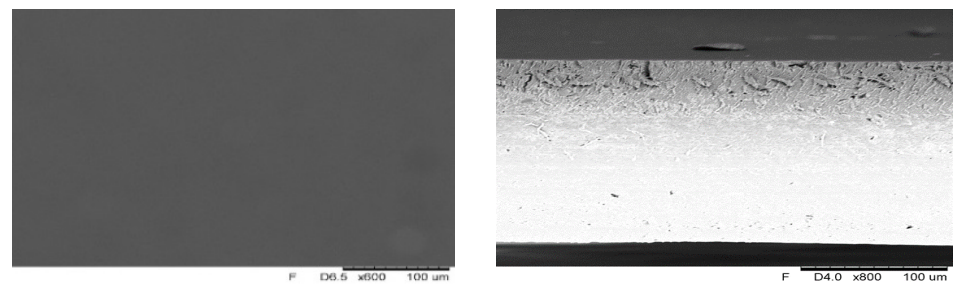

B
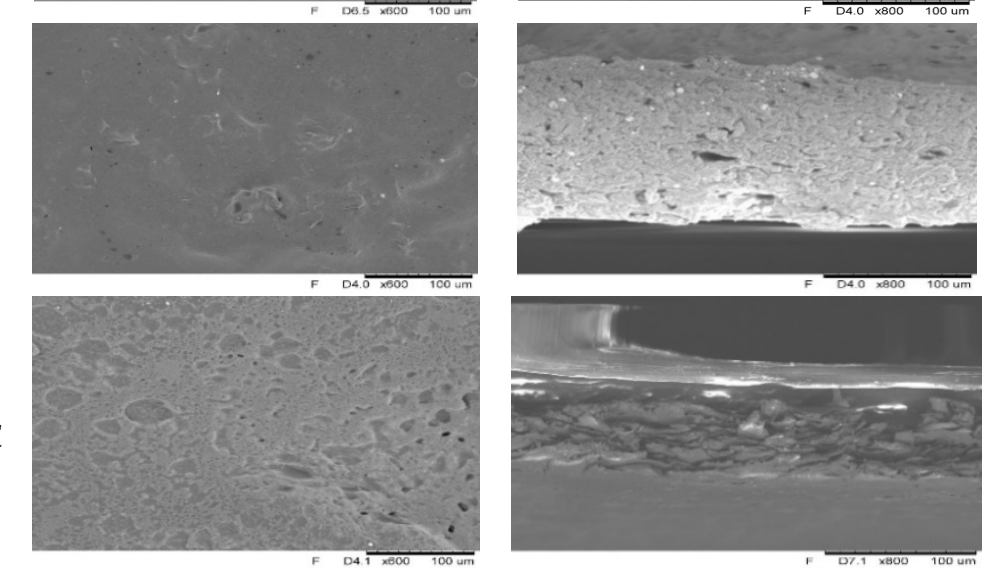

$\mathrm{D}$
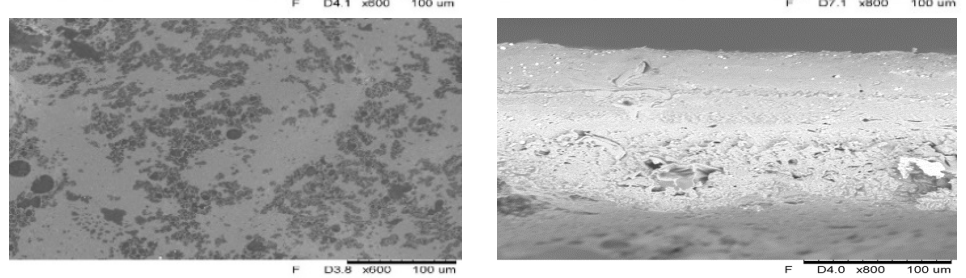

Figure 3. Cont. 
E

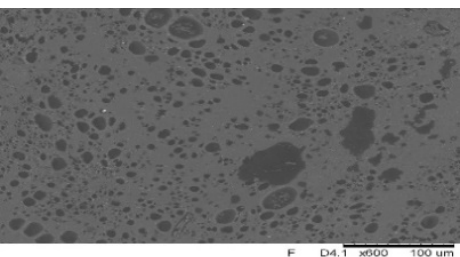

F

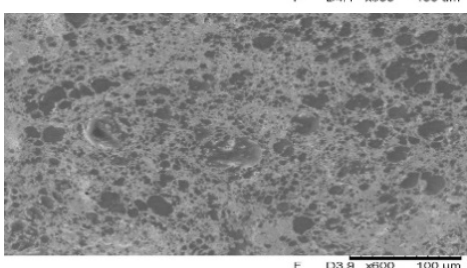

G

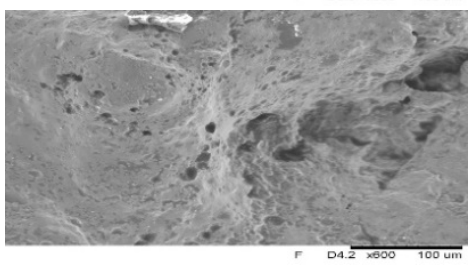

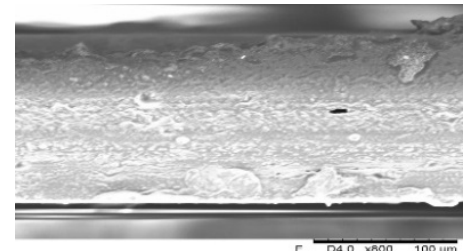
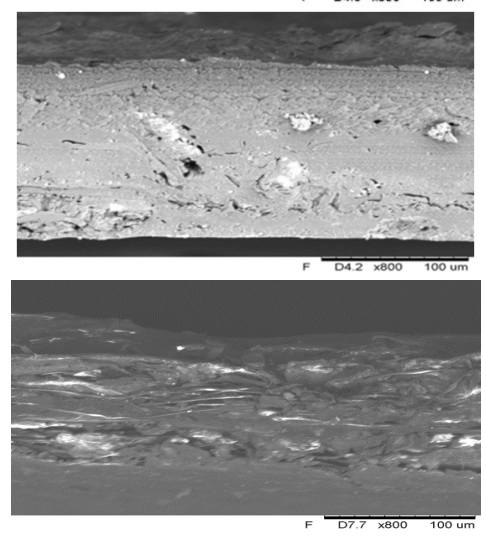

Figure 3. Film micrographs of surfaces and cross-sections of soy protein isolate-oilseed flour films (A-SPI, B-SPI_Flaxseed, C_SPI_Hempseed, D_SPI_Sesameseed, E-SPI_Sunflowerseed, F-SPI_ Evening_primroseseed, G_SPI_Pumpkinseed).

\subsection{Mechanical Properties}

The restriction of the use of edible films is often due to poor mechanical properties compared to packaging made of synthetic polymers [42]. The tensile strength, elongation and Young's modulus values are given in Table 4 . Figure 4 presents the curves showing the relationship between the force required to break the sample and time. The curves showing the stretching dependence of edible films obtained from evening primrose, flaxseed and sunflower flours are characterized by the greatest stretch. Edible films obtained from sesame flour and pumpkin seed flour turned out to be the least stretchy. Generally, all films with the addition of oilseed flour were characterized by low values of mechanical strength However, the edible films obtained on the basis of evening primrose flour, characterized by evenly distributed fat droplets (Figure 3), with a fairly regular shape, achieved the highest tensile strength. Moreover, the film based on evening primrose flour was also characterized by the highest thickness value (173.50 \pm 15.21$)$ (Table 1$)$.

Table 4. Mechanical properties of films prepared with oilseed flours.

\begin{tabular}{cccc}
\hline Film & $\begin{array}{c}\text { Tensile Strength } \\
(\mathbf{M P a})\end{array}$ & $\begin{array}{c}\text { Young's Modulus } \\
\mathbf{( M P a )}\end{array}$ & $\begin{array}{c}\text { Elongation at Break } \\
\mathbf{( \% )}\end{array}$ \\
\hline SPI & $1.74 \pm 0.23^{\mathrm{c}}$ & $1.19 \pm 0.37^{\mathrm{a}}$ & $3.95 \pm 0.15^{\mathrm{c}}$ \\
SPI_Evening_primroseseed & $3.09 \pm 0.34^{\mathrm{d}}$ & $18.75 \pm 4.40^{\mathrm{d}}$ & $24.54 \pm 4.75^{\mathrm{b}}$ \\
SPI_Flaxseed & $2.04 \pm 0.36^{\mathrm{c}}$ & $10.20 \pm 2.33^{\mathrm{c}}$ & $20.03 \pm 3.37^{\mathrm{ab}}$ \\
SPI_Hempseed & $1.21 \pm 0.19^{\mathrm{b}}$ & $5.12 \pm 1.72^{\mathrm{b}}$ & $16.57 \pm 3.87^{\mathrm{a}}$ \\
SPI_Pumpkinseed & $0.82 \pm 0.23^{\mathrm{a}}$ & $1.85 \pm 0.94^{\mathrm{a}}$ & $8.49 \pm 2.46^{\mathrm{d}}$ \\
SPI_Sesameseed & $0.60 \pm 0.24^{\mathrm{a}}$ & $1.01 \pm 0.72^{\mathrm{a}}$ & $6.04 \pm 2.60^{\mathrm{cd}}$ \\
SPI_Sunflowerseed & $1.28 \pm 0.15^{\mathrm{b}}$ & $6.36 \pm 1.14^{\mathrm{b}}$ & $19.77 \pm 1.97^{\mathrm{ab}}$ \\
\hline
\end{tabular}

Mean values with standard deviations in brackets. Different superscript letters $\left({ }^{a-d}\right)$ within the same column indicate significant differences between the films $(p<0.05)$. 


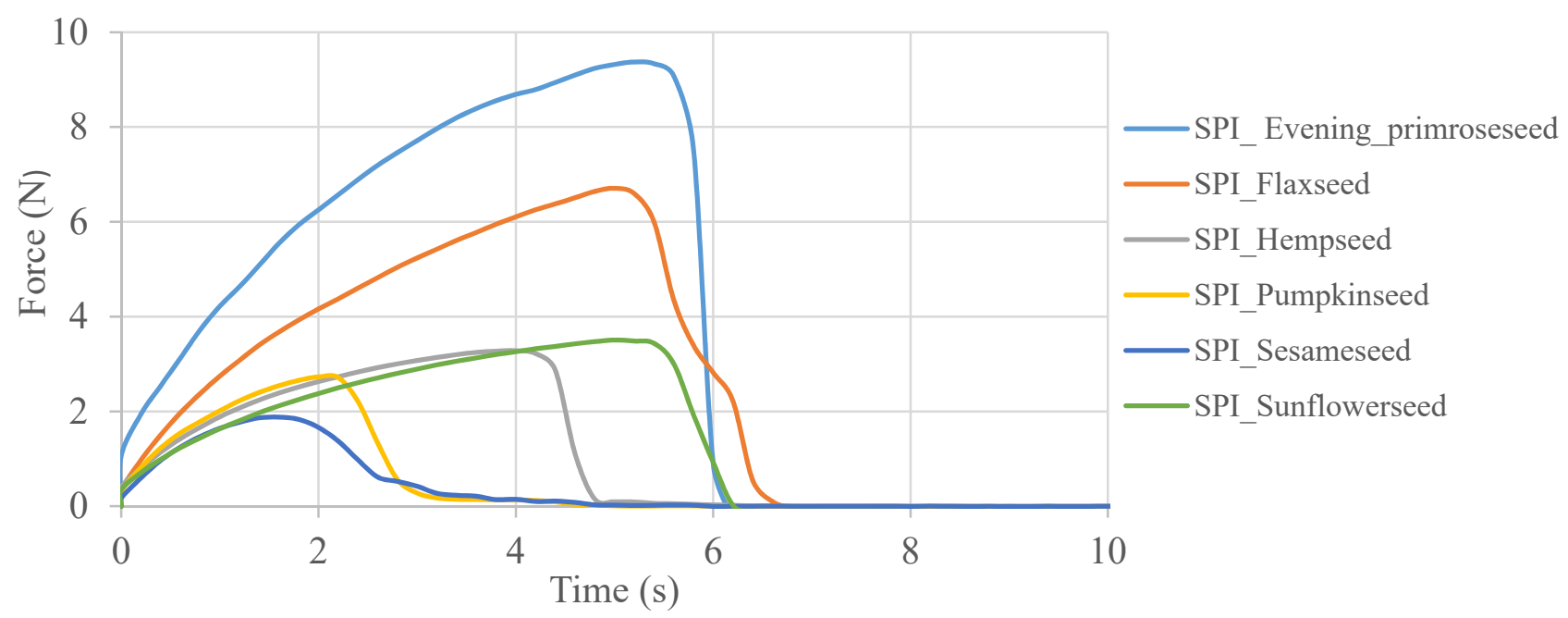

Figure 4. Force-time curves occurring during the tensile strength analysis of soy protein isolate-oilseed flour films.

After comparing the properties of the films, significant differences were observed. The tensile strength values ranged from 0.59 to $3.09 \mathrm{MPa}$. Considering the use of the same amount of glycerol in the preparation of film-forming solutions in order to facilitate processing, it can be concluded that the differences in mechanical properties depended only on the types of biopolymers and their structure. The differences in mechanical properties might also be influenced by differences in thickness, as well as different water contents in the obtained films. According to the standards, in order for edible films to be used as biodegradable packaging materials, they should have a tensile strength above $3.5 \mathrm{MPa}$. The addition of a plasticizer, which was glycerol, caused a decrease in the affinity between the starch chains in the starch matrix. As a result, the formation of hydrogen bonds between the plasticizer and starch resulted in greater flexibility of the film [19]. The best mechanical properties were demonstrated by the film based on evening primrose flour, which contained the most carbohydrates in its composition compared to other flours. The high tensile value shows a homogeneous flour dispersion in the resulting edible film. High tensile strength values were obtained by Andrade-Pizarro, Skurtys and Osorio-Lira [13] during the production of gelatin films from cellulose nanofibers (23.50 and $52.72 \mathrm{MPa}$ ). Taking into account the parameter of the relative elongation of the films, it was observed that the control film had the lowest value (3.95\%). After the research, it was found that the addition of flour increases the elongation of the edible films. Moreover, it was observed that for all the samples prepared with the addition of oilseed flour, the tensile strength increased as the elongation of the sample decreased. The higher the Young's modulus value, the greater the stiffness of the coating material. Ramadhani, Rostini, Anna and Rochima [43] obtained values of elongation of flour films from seaweed plasticized with glycerol in the range of $18.3-86.7 \%$. The value of Young's modulus for the obtained coatings ranged from $1.19 \pm 0.37 \mathrm{MPa}$ for the control film to $18.75 \pm 4.40 \mathrm{MPa}$ for the evening primrose flour film. Young's modulus values in the range $4.9 \pm 0.4-9.3 \pm 0.7 \mathrm{MPa}$ were observed by Gutiérrez, Herniou-Julien, Álvarez and Álvarez [44] when obtaining films from guinea starch arrowroot. Edible films prepared from soy protein and galactomannan, the fraction extracted from the seeds of Gleditsia triacanthos (Fabaceae), were characterized by tensile strengths of $2.58 \pm 0.08 \mathrm{MPa}$ and $3.72 \pm 0.04 \mathrm{MPa}$ depending on the proportions used. Additionally, these edible films had a greater elongation at break of $27.4 \pm 2.4 \%$ and $38.0 \pm 3.0 \%[45]$.

\subsection{Thermal Properties}

The thermogravimetric analysis (TGA) curves and their first derivatives (dTG) are presented in Figure 5 and were investigated to assess the thermal stability of the films (Table 5). The dTG curves were shifted vertically for easier comparison. It can be observed 
that all analyzed films showed a similar behavior with three main stages of weight loss (Figure 5). The first stage was observed up to $100{ }^{\circ} \mathrm{C}$ and was related to the loss of the adsorber and bound water.

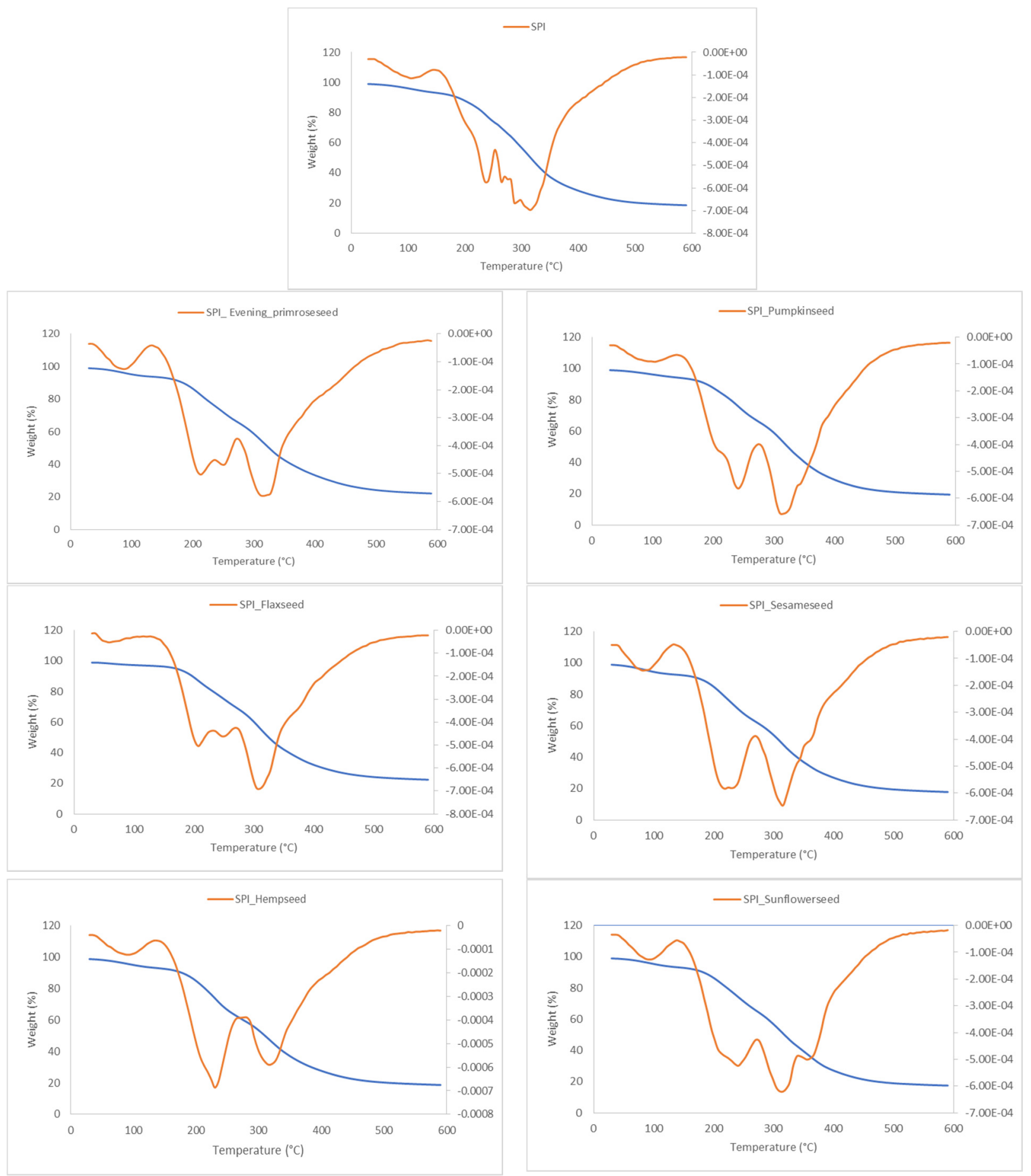

Figure 5. Thermogravimetric analysis (TGA) (blue) and derivative thermogravimetry (dTG) (orange) curves of films of soy protein isolate and oilseed flour. 
Table 5. Temperature and weight loss related to stages of TG/dTG curves of soy protein isolate-oilseed flour films.

\begin{tabular}{|c|c|c|c|c|c|c|}
\hline \multirow[b]{2}{*}{ Film } & \multicolumn{2}{|c|}{ First Stage } & \multicolumn{2}{|c|}{ Second Stage } & \multicolumn{2}{|c|}{ Third Stage } \\
\hline & $\begin{array}{c}\text { Temperature } \\
\left({ }^{\circ} \mathrm{C}\right)\end{array}$ & $\begin{array}{l}\text { Weight Loss } \\
(\%)\end{array}$ & $\begin{array}{c}\text { Temperature } \\
\left({ }^{\circ} \mathrm{C}\right)\end{array}$ & $\begin{array}{l}\text { Weight Loss } \\
(\%)\end{array}$ & $\begin{array}{c}\text { Temperature } \\
\left({ }^{\circ} \mathrm{C}\right)\end{array}$ & $\begin{array}{c}\text { Weight Loss } \\
(\%)\end{array}$ \\
\hline SPI & 99.98 & 7.06 & 266.2 & 7.41 & 320.7 & 20.96 \\
\hline $\begin{array}{c}\text { SPI_ } \\
\text { Evening_primroseseed }\end{array}$ & 82.09 & 6.25 & 210.6 & 17.88 & 318.4 & 13.93 \\
\hline SPI_Flaxseed & 53.20 & 3.47 & 205.1 & 15.84 & 310.7 & 13.07 \\
\hline SPI_Hempseed & 85.87 & 6.85 & 230.6 & 19.75 & 320.33 & 12.83 \\
\hline SPI_Pumpkinseed & 86.79 & 5.88 & 242.4 & 18.13 & 316.8 & 14.53 \\
\hline SPI_Sesameseed & 80.12 & 7.65 & 218.6 & 29.81 & 316.9 & 35.41 \\
\hline SPI_Sunflowerseed & 86.38 & 7.04 & 242.2 & 28.49 & 318.3 & 37.44 \\
\hline
\end{tabular}

Usually, the first stage, from 25 to $200{ }^{\circ} \mathrm{C}$, is attributed to the evaporation of water and molecules with a molecular weight [46]. The film composition affected this stage. Soy protein films without oilseed flours showed the highest temperature $\left(99.98^{\circ} \mathrm{C}\right)$, whereas films containing flaxseed flour showed the lowest temperature $\left(53.20^{\circ} \mathrm{C}\right)$ and lowest weight loss $(3.47 \%)$, which is connected with a lower thermal stability. Other films exhibited weight loss from 5.88 to $7.65 \%$ at the range of temperature from 80.12 to $86.79{ }^{\circ} \mathrm{C}$. Similar results, were reported by Tongnuanchan et al. [47] for fish gelatin films incorporated with palm oil. The second stage of the degradation temperature appeared approximately between 205.1 and $266.2{ }^{\circ} \mathrm{C}$ for films containing flaxseed flour and soy films without oilseed flours, respectively.

Soy films showed the highest temperature, and the addition of flours decreased this initial stage, resulting in lower stability, which may be due to the decomposition of protein fractions of a lower molecular weight. Regarding weight loss, it can be observed that at the second stage, the lowest value was observed for soy films $(7.41 \%)$ and highest for films containing sunflower seed flour $(28.49 \%)$ and sesame seed flour $(29.81 \%)$. In general, the second stage, from 200 to $350{ }^{\circ} \mathrm{C}$, is attributed to the thermal decomposition of the components in the analyzed films. According to the previous works, protein breakdown starts at the temperature of $225^{\circ} \mathrm{C}$ [48], and the decomposition of starch is related to the temperature from 230 to $326^{\circ} \mathrm{C}$ [49]. In the third stage, all films presented similar minor degradation temperatures, between 310.7 and $320.7^{\circ} \mathrm{C}$. However, the weight loss was at $20.96 \%$ for soy films and varied for other films between 12.83 and $14.53 \%$ for films with evening primrose seed, flaxseed and hemp seed flours, and between 25.41 and $37.44 \%$ for films containing sesame seed and sunflower seed flours, respectively. In general, in the third stage, above $350{ }^{\circ} \mathrm{C}$, the degradation of carbonaceous residues which were formed during the second stage can be observed, combined with the complex oxidation of these materials [50]. Therefore, the thermogravimetric analysis demonstrated that the blending of soy protein with oilseed flours decreased the stability of soy films observed by the lower heat resistance and intra/intermolecular protein interactions of the analyzed films. This was better observed for the first and second stages when degradation occurred at lower temperatures. This can be attributed to the film composition, especially the lipid content, which was different for oilseed flours, and was from $6 \%$ for hemp flour to $16 \%$ for pumpkin seed flour, as well as the protein content, from $29 \%$ for evening primrose seed flour to $58 \%$ for pumpkin seed flour. In addition, the lower stability of the blended films might also be due to the destruction of hydrogen bonds between the protein and other molecules.

\section{Materials and Methods}

\subsection{Materials}

Soy protein isolate (SUPRO 670, $95 \mathrm{~g}$ protein) was purchased from The Solae Company (DuPont, Warsaw, Poland). Oilseed flours (evening primrose, flax, hemp, pumpkin, sesame and sunflower) were produced by PPHU Machines and Processing of Oil Seeds Ol'Vita Krzysztof Dziaduch (Pszenno, Poland) and The Helcom Company (Helcom, Greek 
Trade Sp. z o.o., Kraków, Poland). Anhydrous glycerol, sodium hydroxide and sodium chloride were purchased from Avantor Performance Materials Poland S.A. (Gliwice, Poland).

\subsubsection{Characterization of Oilseed Flours}

The oilseed flours' particle size distribution was determined by sieve analysis with a vibratory sieve shaker model AS 200 (Retsch, Katowice, Poland) using a sieve aperture of 150, 150, 355, 500 and $710 \mu \mathrm{m}$ for $10 \mathrm{~min}$ of sieving time. Table 6 shows the basic chemical composition of oilseed flours that were used to obtain edible films.

Table 6. Chemical composition of selected oilseed flours (in $100 \mathrm{~g}$ of the product).

\begin{tabular}{|c|c|c|c|c|c|c|}
\hline & $\begin{array}{c}\text { Evening } \\
\text { Primroseed }\end{array}$ & Flaxseed & Hempseed & Pumpkinseed & Sesameseed & Sunflowerseed \\
\hline Energy (kcal) & 363.8 & 316 & 356 & 425.2 & 397.5 & 346 \\
\hline Fat $(\mathrm{g})$ & 8 & 8.9 & 6 & 16 & 10 & 9.5 \\
\hline of which saturates $(\mathrm{g})$ & 1 & 0.8 & 1 & 3 & 2 & 1.2 \\
\hline Carbohydrate $(\mathrm{g})$ & 45 & 4.8 & 41 & 13 & 21 & 8 \\
\hline of which sugars (g) & 1 & 4.1 & 3 & 1 & 1 & 6.5 \\
\hline Protein $(\mathrm{g})$ & 29 & 38 & 38 & 58 & 55 & 48 \\
\hline Salt (g) & 0 & 0.16 & 0 & 0 & 0 & 0.01 \\
\hline
\end{tabular}

\subsubsection{Film Preparation}

Films were prepared according to the casting method. Aqueous film-forming solutions were prepared from a mixture of oilseed flour and soy protein isolate at the concentration of $5 \%(w / w)$ and were mixed at $70 \pm 1{ }^{\circ} \mathrm{C}$ for 20 min under $250 \mathrm{rpm}$ with a constant magnetic stirrer, model RTC basic IKAMAG (IKA-Werke GmbH \& Co., Staufen, Germany). Then, solutions were cooled down to $25 \pm 1{ }^{\circ} \mathrm{C}$, and glycerol (plasticizer) at $50 \%(w / w)$ was added. Control film-forming aqueous solutions were prepared without oilseed flours at the concentration of $10 \%(w / w)$ of soy protein isolate and with the addition of glycerol $(50 \%)$. The $\mathrm{pH}$ of the prepared film-forming solutions using a $\mathrm{pH}$ meter (CPO-505, Warsaw, Poland) was adjusted to 10.0 with $1 \mathrm{M} \mathrm{NaOH}$ (sodium hydroxide) solution. The obtained film-forming solutions were poured into Petri dishes with a diameter of $10 \mathrm{~cm}$ in the amount of $10 \mathrm{~mL}$.

The films were dried in a thermostatic chamber, model KBF 720 (Binder, Tuttlingen, Germany), at $25{ }^{\circ} \mathrm{C}$ and relative humidity of $50 \%$ for $24 \mathrm{~h}$. Then, all films were removed from the Petri dishes and were conditioned for $48 \mathrm{~h}$ at $25^{\circ} \mathrm{C}$ and relative humidity of $50 \%$ prior to testing (Figure 6). 


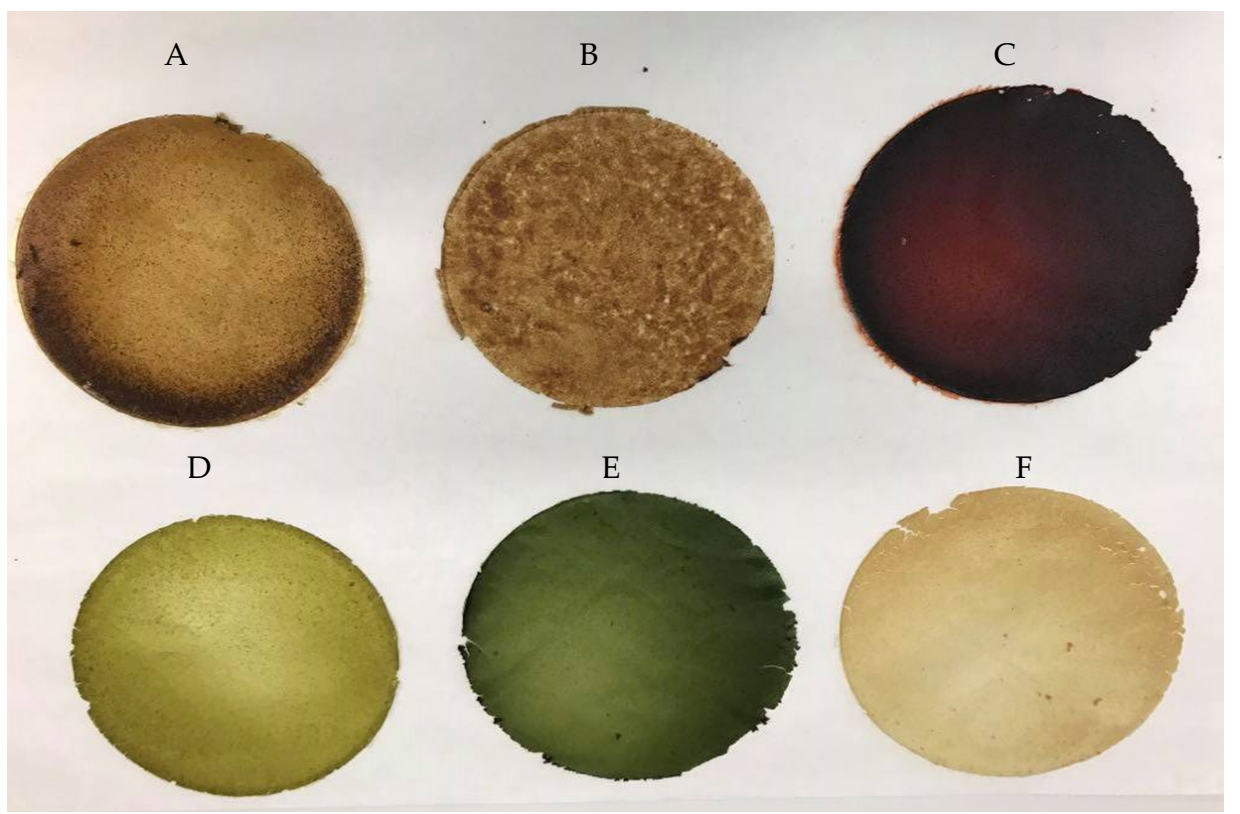

Figure 6. Edible films based on soy protein isolate and oilseed flours (A-SPI_Hempseed; B-SPI_Flaxseed; C-SPI_Evening_primroseseed; D-SPI_Pumpkinseed; E-SPI_Sunflowerseed; F-SPI_Sesameseed).

\subsection{Physical Properties}

\subsubsection{Water Content}

The water content was determined by the drying method at $105^{\circ} \mathrm{C}$ for $24 \mathrm{~h}$ (dryer SUP 65 W/G, WAMED, Warsaw, Poland). Then, the percentage of dry residue present in the sample was calculated. The measurement was performed in triplicate.

\subsubsection{Thickness}

The thickness of films was determined using an electronic gauge Ultrameter A400 (Metrison, Mościska, Poland) with the precision of $1 \mu \mathrm{m}$. The results were obtained by measuring the thickness at ten random points, and then the mean and the standard deviation were calculated.

\subsubsection{Water Solubility}

The prepared samples of edible films were cut into squares $(20 \times 20 \mathrm{~mm})$. The samples were then dried at $105^{\circ} \mathrm{C}$ for $24 \mathrm{~h}$. After this time, the samples were cooled in a desiccator containing silica gel. The samples were reweighed and placed in $25 \mathrm{~mL}$ of distilled water. After $24 \mathrm{~h}$ of storage, excess water was removed with filter paper. The samples were dried for $24 \mathrm{~h}$ at $105^{\circ} \mathrm{C}$ and reweighed. The water solubility of the edible films was determined in three repetitions and was calculated based on the method described by Rhim, Lee and $\mathrm{Ng}$ [51].

\subsubsection{Swelling Index}

This parameter was determined according to the method of Cao, Fu and He [52]. The film specimen was cut into square pieces $(20 \times 20 \mathrm{~mm})$, and a piece of the edible film was accurately weighted. The film sample was placed in a glass beaker containing $25 \mathrm{~mL}$ of distilled water for $2 \mathrm{~min}$. Then, all samples were drained and weighed, and the swelling index was calculated as the percentage of swelled water. The measurement was performed in three repetitions.

\subsubsection{Film Opacity}

Opacity was determined according to the spectrophotometric method using the UV/VIS Helios Gamma spectrophotometer (Thermo Electron Corporation, Bath, UK). 
The absorbance was measured at $600 \mathrm{~nm}$ on $100 \times 400 \mathrm{~mm}$ samples in ten repetitions, and an empty test cell was used as reference. The opacity of the prepared material was calculated according to the method described by Han and Floros [53] and expressed as absorbance per film thickness in $\mathrm{mm}$.

\subsubsection{Color}

The color test was performed using the CIE $L^{*} a^{*} b^{*}$ system $\left(L^{*}\right.$-brightness, $a^{*}$-green to red color, $\mathrm{b}^{*}$-blue to yellow color) using the CR-300 model colorimeter (Minolta, Tokyo, Japan). The measurement was performed in ten repetitions. For a better interpretation, the formula for the total color difference $(\Delta \mathrm{E})$ between the film and the white standard $\left(\mathrm{L}^{*}=99.27 \pm 0.10 ; \mathrm{a}^{*}=0.019 \pm 0.06 ; \mathrm{b}^{*}=1.23 \pm 0.19\right)$ was calculated according to the method described by Sobral, dos Santos and Garcia [54].

\subsection{Water Vapor Permeability (WVP), Sorption and Diffusion}

The water vapor permeability of the obtained films was determined by the gravimetric method (Debeaufort, Martin-Polo and Voilley, 1993) [55]. An RH difference of (50-100\%) at a temperature of $25 \pm 1{ }^{\circ} \mathrm{C}$ was used. At least three replicates were performed for each film type, and the WVP was determined at steady state and from the change in the cell mass as a function of time.

The water vapor sorption kinetics were measured after $0.5,1,3,6,9,12,24,48,72$, 96 and $120 \mathrm{~h}$ under constant temperature of $25^{\circ} \mathrm{C}$ and relative humidity of $75.3 \%$. For each type of film, at least 3 repetitions were performed. The kinetic curves were plotted as graphs showing the dependence of the change in the amount of adsorbed water on the time of the process.

The water vapor diffusion coefficient was estimated by approximation and valid for the used testing conditions only according to the method described by Galus et al. [56] based on Fick's second law (Crank, 1975) [57].

\subsection{Microstructure}

The films were previously cut into small squares of $5 \times 5 \mathrm{~mm}$ and fixed on a metallic cylindrical support. Film surfaces and film cross-sections were analyzed by scanning electron microscopy (FEI Company, Quanta 200 MK2, Fremont, CA, USA) at a magnification of $\times 600$ (surfaces) and x800 (cross-sections).

\subsection{Mechanical Properties}

The ASTM standard method D882-02 (ASTM, 2002) was used to determine tensile strength (TS), elongation at break (E) and Young's modulus (YM) of the analyzed films. The Texture Analyzer TA-XT2i (Stable Micro Systems, Haslemere, UK) with the Texture Expert software was used to process the results. Measurements of the mechanical properties of the edible films were performed in at least six repetitions.

\subsection{Thermal Properties}

Thermogravimetric analyses were performed using a TGA thermal analyzer (Mettler Toledo, Warszawa, Poland) to determine thermal stability and degradation of the films. Each film sample $(5 \mathrm{mg})$ was heated at $5{ }^{\circ} \mathrm{C} \mathrm{min}^{-1}$ from 30 to $600{ }^{\circ} \mathrm{C}$ under nitrogen

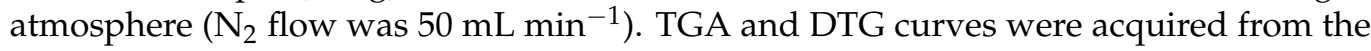
differential TGA values.

\subsection{Statistical Analysis}

The results were evaluated by one-way analysis of variance (ANOVA) using the software Statistica 13.0 (StatSoft Inc., Kraków, Poland). Tukey's post hoc test was performed to compare the results, expressed by mean $( \pm)$ standard deviation, at the level of significance of 0.05 . 


\section{Conclusions}

It was found that the addition of oilseed flour is a good base material for the preparation of composite edible films. The type of flour used influenced the differentiation of the film properties as well as their functionality. The addition of flours shows that the use of the correct type of flour makes it possible to improve the effectiveness of the film used as a moisture barrier or its adsorptive properties. The results obtained in this study suggest that the oilseed flours added to film-forming solutions are promising materials that can be used in the development of biodegradable films and applied in the food industry for packaging food products. The best mechanical properties and the greatest durability were achieved in the preparation of evening primrose flour films. From the practical point of view, the analyzed soy protein-oilseed flour films can be applied as edible protective coatings for different products, including vegetable bars, burgers or other processed foods based on vegetables or seeds.

Author Contributions: Conceptualization: S.G.; methodology: S.G.; validation: M.M. and S.G.; software: M.M. and S.G.; formal analysis: M.M. and S.G.; investigation: M.M. and S.G.; resources: M.M. and S.G.; data curation: M.M. and S.G.; writing_-original draft preparation: M.M. and S.G.; writing—review and editing: M.M., S.G., A.C. and M.J.; visualization: M.M. and S.G.; supervision: S.G. and M.J.; project administration: M.J.; funding acquisition: M.J. All authors have critically revised and contributed to the final version of this manuscript. All authors have read and agreed to the published version of the manuscript.

Funding: This research was funded by Nasional Center for Research and Development, grant number BIOSTRATEG / 343817/17 / NCBR / 2018. This work was also co-financed by a statutory activity subsidy from the Polish Ministry of Science and Higher Education for the Faculty of Food Technology of Warsaw University of Life Sciences. Research equipment was purchased as part of "Food and Nutrition Centre-modernization of the WULS campus to create a Food and Nutrition Research and Development Centre (CŻiŻ)" co-financed by the European Union from the European Regional Development Fund under the Regional Operational Programme of the Mazowieckie Voivodeship for 2014-2020 (Project No. RPMA.01.01.00-14-8276/17).

Institutional Review Board Statement: Not applicable.

Informed Consent Statement: Not applicable.

Data Availability Statement: Data sharing not applicable.

Acknowledgments: The authors thank to Katarzyna Rybak for her help during termogravimetric analysis (TGA).

Conflicts of Interest: The authors declare no potential conflicts of interest with respect to the research, authorship and/or publication of this article.

Sample Availability: Samples of the films are available from the authors.

\section{References}

1. Díaz, O.; Ferreiro, T.; Rodríguez-Otero, J.L.; Cobos, A. Characterization of chickpea (Cicer arietinum L.) flour films: Effect of $\mathrm{pH}$ and plasticizer concentration. Int. J. Mol. Sci. 2019, 20, 1246. [CrossRef]

2. Giosafatto, C.V.L.; Al-Asmar, A.; D'Angelo, A.; Roviello, V.; Esposito, M.; Mariniello, L. Preparation and characterization of bioplastics from grass pea flour cast in the presence of microbial transglutaminase. Coatings 2018, 8, 435. [CrossRef]

3. Hassan, B.; Chatha, S.A.S.; Hussain, A.I.; Zia, K.M.; Akhtar, N. Recent advances on polysaccharides, lipids and protein based edible films and coatings: A review. Int. J. Biol. Macromol. 2018, 109, 1095-1107. [CrossRef]

4. Galus, S. Functional properties of soy protein isolate edible films as affected by rapeseed oil concentration. Food Hydrocoll. 2018, 85, 233-241. [CrossRef]

5. Lamo, B.; Gómez, M. Bread enrichment with oilseeds. A review. Foods 2018, 7, 191. [CrossRef]

6. Kaszuba, J.; Pycia, K.; Wiśniewski, R.; Jaworska, G.; Kuźniar, P. Effect of selected oil-bearing plant seeds contained in triticale bread on its quality. Żywoność. Nauka. Technol. Jakość 2017, 24, 90-102. [CrossRef]

7. Galus, S.; Arik Kibar, A.E.; Gniewosz, M.; Kraśniewska, K. Novel materials in the preparation of edible films and coatings-A review. Coatings 2020, 10, 674. [CrossRef]

8. Guimarães, R.M.; Ida, E.I.; Falcão, H.B.; de Rezende, T.A.M.; de Santana Silva, J.; Alves, C.C.F.; da Silva, M.A.P.; Egea, M.B. Evaluating technological quality of okara flours obtained by different drying processes. LWT 2020, 123, 109062. [CrossRef] 
9. Nouraddini, M.; Esmaiili, M.; Mohtarami, F. Development and characterization of edible films based on eggplant flour and corn starch. Int. J. Biol. Macromol. 2018, 120, 1639-1645. [CrossRef]

10. Vera, A.; Tapia, C.; Abugoch, L. Effect of high-intensity ultrasound trearment in combination with transglutaminase and nanoparticles on structural, mechanical, and physicochemical properties of quinoa proteins/chitosann edible films. Int. J. Biol. Macromol. 2020, 144, 536-543. [CrossRef]

11. Dick, M.; Henrique Pagno, C.; Haas Costa, T.M.; Gomaa, A.; Subirade, M.; de Oliveira Rios, A.; Hickmann Flores, S. Edible films based on chia flour: Development and characterization. J. Appl. Polym. Sci. 2016, 133, 1-9. [CrossRef]

12. Ochoa-Yepes, O.; Medina-Jaramillo, C.; Guz, L.; Famá, L. Biodegradable and edible starch composites with fiber-rich lentil flour to use as food packaging. Starch/Straerke 2018, 70,1-34. [CrossRef]

13. Andrade-Pizarro, R.D.; Skurtys, O.; Osorio-Lira, F. Effect of cellulose nanofibers concentration on mechanical, optical, and barrier properties of gelatin-based edible films. Dyna 2015, 82, 219-226. [CrossRef]

14. Czerwińska, D. Charakterystyka i zastosowanie mąki z nasion roślin oleistych. Prz. Zboż. Młyn. 2010, $54,16-17$.

15. Sharma, L.; Saini, C.S.; Sharma, H.K.; Sandhu, K.S. Biocomposite edible coatings based on cross linked-sesame protein and mango puree for the shelf life stability of fresh-cut mango fruit. J. Food Process Eng. 2018, 42, 1-9. [CrossRef]

16. Patwa, A.; Malcolm, B.; Wilson, J.; Amrose, R.P.K. Particle size analysis of two distinct classes of wheat flour by sieving. ASABE 2016, 57, 151-159. [CrossRef]

17. Adjei-Fremah, S.; Worku, M.; Erive, M.O.D.; He, F.; Wang, T.; Chen, G. Effect of microfluidization on microstructure, protein profile and physicochemical properties of whole cowpea flours. Innov. Food Sci. Emerg. Technol 2019, 57, 1-10. [CrossRef]

18. Pająk, P.; Przetaczek-Rożnowska, I.; Juszczak, L. Development and physicochemical, thermal and mechanical properties of edible films based on pumpkin, lentil and quinoa starches. Int. J. Biol. Macromol. 2019, 138, 441-449. [CrossRef]

19. Basiak, E.; Lenart, A.; Debeaufort, F. How glycerol and water contents affect the structural and functional properties of starchbased edible films. Polymers 2018, 10, 412. [CrossRef]

20. Andrade-Mahecha, M.M.; Tapia-Blácido, D.R.; Menegalli, F.C. Development and optimization of biodegradable films based on achira flour. Carbohydr. Polym. 2012, 88, 449-458. [CrossRef]

21. Daudt, R.M.; Avena-Bustillos, R.J.; Williams, T.; Wood, D.F.; Külkamp-Guerreiro, I.C.; Marczak, L.D.F.; McHugh, T.H. Comparative study on properties of edible films based on pinhão (Araucaria angustifolia) starch and flour. Food Hydrocoll. 2016, 60, 279-287. [CrossRef]

22. Chandla, N.K.; Khatkar, S.K.; Singh, S.; Saxena, D.C.; Jindal, N.; Bansal, V.; Wakchaure, N. Tensile strength and solubility studies of edible biodegradable films developed from pseudo-cereal starches: An inclusive comparison with commercial corn starch. Asian J. Dairy Food Res. 2020, 39, 139-146. [CrossRef]

23. Liu, C.; Huang, J.; Zheng, X.; Liu, S.; Lu, K.; Tang, K.; Liu, J. Heat sealable soluble soybean polysaccharide/gelatin blend edible films for food packaging applications. Food Packag. Shelf Life 2020, 24, 100485. [CrossRef]

24. Aydogdu, A.; Kirtil, E.; Sumnu, G.; Oztop, M.H.; Aydogdu, Y. Utilization of lentil flour as a biopolymer source for the development of edible films. Inc. J. Appl. Polym. Sci. 2018, 135, 46356. [CrossRef]

25. Basiak, E.; Lenart, A.; Debeaufort, F. Effect of starch type on the physico-chemical properties of edible films. Int. J. Biol. Macromol. 2017, 98, 348-356. [CrossRef] [PubMed]

26. Gutiérrez, T.J. Are modified pumpkin flour/plum flour nanocomposite films biodegradable and compostable? Food Hydrocoll. 2018, 83, 397-410. [CrossRef]

27. Tian, H.; Guo, G.; Fu, X.; Yao, Y.; Yuan, L.; Xiang, A. Fabrication, properties and applications of soy-protein-based materials: A review. Int. J. Biol. Macromol. 2018, 48, 603-606. [CrossRef] [PubMed]

28. Basiak, E.; Debeaufort, F.; Lenart, A. Effect of oil lamination between plasticized starch layers on film properties. Food Chem. 2016, 195, 56-63. [CrossRef]

29. Acquah, C.; Zhang, Y.; Dube, M.A.; Udenigwe, C. Formation and characterization of protein-based films from yellow pea (Pisum sativum) protein isolate and concentrate for edible applications. Curr. Res. Nutr. Food Sci. 2020, 2, 61-69. [CrossRef] [PubMed]

30. Zheng, T.; Yu, X.; Pilla, S. Mechanical and moisture sensitivity of fully bio-based dialdehyde carboxymethyl cellulose cross-linked soy protein isolate films. Carbohydr. Polym. 2017, 10, 1333-1340. [CrossRef] [PubMed]

31. Silva, A.O.; Cortez-Vega, W.R.; Prentice, C.; Fonseca, G.G. Development and characterization of biopolimer films based on bocaiuva (Acromonia aculeata) flour. Int. J. Biol. Macromol. 2019, 155, 1157-1168. [CrossRef] [PubMed]

32. Shevkani, K.; Singh, N. Relationship between protein characteristics and film-forming properties of kidney bean, field pea and amaranth protein isolates. Int. J. Food Sci. Technol. 2015, 50, 1033-1043. [CrossRef]

33. Ortiz, C.M.; Oliveira de Moraes, J.; Vicente, A.R.; Laurindo, J.B.; Mauri, A.N. Scale-up of the production of soy (Glycine max L.) protein films using tape casting: Formulation of film-forming suspension and drying conditions. Food Hydrocoll. 2017, 66, 110-117. [CrossRef]

34. De Faria Arquelau, P.B.; Silva, V.D.M.; Garcia, M.A.V.T.; de Araujo, R.L.B.; Fante, C.A. Characterization of edible coatings based on ripe 'Prata' banana peel flour. Food Hydrocoll. 2019, 89, 570-578. [CrossRef]

35. Anonymous. Barwa i Jakość; Heidelberg Druckmaschinen AG: Kurfursten-Anlage, Germany, 1999; pp. 52-60.

36. Maniglia, B.C.; Tessaro, L.; Lucas, A.A.; Tapia-Blácido, D.R. Bioactive films based on babassu mesocarp flour and starch. Food Hydrocoll. 2017, 70, 383-391. [CrossRef] 
37. Wu, H.; Lei, Y.; Zhu, R.; Zhao, M.; Lu, J.; Xiao, D.; Zhang, Z.; Shen, G.; Li, S. Preparation and characterization of bioactive edible packaging films based on pomelo peel flours incorporating tea polyphenol. Food Hydrocoll. 2019, 90, 41-49. [CrossRef]

38. Tapia-Blácido, D.R.; do Amaral Sobral, P.J.; Menegalli, F.C. Effect of drying conditions and plasticizer type on some physical and mechanicalproperties of amaranth flour films. LWT 2013, 50, 392-400. [CrossRef]

39. Zhao, X.; Li, W.; Zhang, H.; Li, X.; Fan, W. Reaction-diffusion approach to modeling water diffusion in glutinous rice flour particles during dynamic vapor adsorption. J. Food Sci. Technol. 2019, 56, 4605-4615. [CrossRef]

40. Gutiérrez, T.J.; González, G. Effect of cross-linking with aloe vera gel on surface and physicochemical properties of edible films made from plantain flour. Food Biophys. 2017, 12, 11-22. [CrossRef]

41. Drakos, A.; Kyriakakis, G.; Evageliou, V.; Protonotariou, S.; Mandala, I.; Ritzoulis, C. Influence of jet milling and particle sizeon the composition, physicochemical and mechanical properties of barley and rye flours. Food Chem. 2017, 215, 326-332. [CrossRef]

42. Cazón, P.; Vázquez, M. Mechanical and barrier properties of chitosan combined with other components as food packaging film. Environ. Chem. Lett. 2019, 18, 257-267. [CrossRef]

43. Ramadhani, F.S.; Rostini, I.; Anna, Z.; Rochima, E. Characterization of edible film from seaweed flour (Eucheuma cottonii Weber-van Bosse, 1993) with different types of plasticizer. WSN 2019, 133, 23-33.

44. Gutiérrez, T.J.; Herniou-Julien, C.; Álvarez, K.; Álvarez, V.A. Structural properties and in vitro digestability of edible and $\mathrm{pH}$-sensitive films made from guinea arrowroot starch and wastes from wine manufacture. Carbohydr. Polym. 2018, 184, 135-143. [CrossRef]

45. González, A.; Barrera, G.N.; Galimberti, P.I.; Ribotta, P.D.; Igarzabal, C.I.A. Developmet of edible films prepared by soy protein and the galactomannan fraction extracted grom Gleditsia triacanthos (Fabaceae) seed. Food Hydrocoll. 2019, 97, 105227. [CrossRef]

46. Andrade Martins, Y.A.; Ferreira, S.V.; Silva, N.M.; Sandre, M.F.B.; Filho, J.G.O.; Leão, P.V.T.; Leão, K.M.; Nicolau, E.S.; Plácido, G.R.; Egea, M.B.; et al. Edible Films of Whey and Cassava Starch: Physical, Thermal, and Microstructural Characterization. Coatings 2020, 10, 1059. [CrossRef]

47. Tongnuanchan, P.; Benjakul, S.; Prodpran, T.; Nilsuwan, K. Emulsion film based on fish skin gelatin and palm oil: Physical, structural and thermal properties. Food Hydrocoll. 2015, 48, 248-259. [CrossRef]

48. Muñoz, L.; Aguilera, J.; Rodriguez-Turienzo, L.; Cobos, A.; Diaz, O. Characterization and microstructure of films made from mucilage of Salvia hispanica and whey protein concentrate. J. Food Eng. 2012, 111, 511-518. [CrossRef]

49. Nogueira, G.F.; Fakhouri, F.M.; De Oliveira, R.A. Extraction and characterization of arrowroot (Maranta arundinaceae L.) starch and its application in edible films. Carbohydr. Polym. 2018, 186, 64-72. [CrossRef]

50. Azevedo, V.M.; Borges, S.V.; Marconcini, J.M.; Yoshida, M.I.; Neto, A.R.S.; Pereira, T.C.; Pereira, C.F.G. Effect of replacement of corn starch by whey protein isolate in biodegradable film blends obtained by extrusion. Carbohydr. Polym. 2017, 157, 971-980. [CrossRef]

51. Rhim, J.-W.; Lee, J.H.; Ng, P.K.W. Mechanical and barrier properties of biodegradable soy protein isolate-based films coated with polylactic acid. LWT 2007, 40, 232-238. [CrossRef]

52. Cao, N.; Fu, Y.; He, J. Preparation and physical properties of soy protein isolate and gelatin composite films. Food Hydrocoll. 2007, 21, 1153-1162. [CrossRef]

53. Han, J.H.; Floros, J.D. Casting antimicrobial packaging films and measuring their physical properties and antimicrobial activity. J. Plast. Film Sheet 1997, 13, 287-298. [CrossRef]

54. Sobral, P.J.; dos Santos, J.S.; Garcia, F.T. Effect of protein and plasticizer concentration in film forming solutions on physical properties of edible films based on muscle proteins of a Thai Tilapia. J. Food Eng. 2005, 70, 93-100. [CrossRef]

55. Debeaufort, F.; Martin-Polo, M.; Voilley, A. Polarity and structure affect water vapor permeability of model edible films. J. Food Sci. 1993, 58, 428-434. [CrossRef]

56. Galus, S.; Mathieu, H.; Lenart, A.; Debeaufort, F. Effect of modified starch or maltodextrines incorporation on the barrier and mechanical properties, moisture sensitivity and appearance of soy protein isolate-based edible films. Innov. Food Sci. Emerg. Technol. 2012, 16, 148-154. [CrossRef]

57. Crank, J. Mathematics of Diffusion, 2nd ed.; Oxford Science Publications: Oxford, UK, 1975. 